\title{
Development of Problem-based Mathematic Learning Model to Increase Students' Competence
}

\section{Zulfa Amrina ${ }^{1}$, Rita Desfitri², Fazri Zuzano ${ }^{2}$, Yusri Wahyuni², and Hendra Hidayat ${ }^{1}$ \\ ${ }^{1}$ The Study Program of Teacher Education of Primary School, FKIP, Universitas Bung Hatta \\ ${ }^{2}$ The Study Program of Mathematic Education, FKIP, Universitas Bung Hatta}

\section{Abstract}

This study aims at producing a problem-based valid, practical, and effective mathematic learning model to improve students' competence. The students' competence investigated included the ability to think logically, critically, and creatively. The stages of developing a problem-based mathematic learning model consist of 1) preliminary stage, 2) proto-type stage including planning, evaluation, and revision, 3) product assessment

Corresponding Author:

Zulfa Amrina

zulfa.amrina@bunghatta.ac.id

Received: 18 January 2019

Accepted: 24 March 2019

Published: 31 March 2019

Publishing services provided by Knowledge E

(c) Zulfa Amrina et al. This article is distributed under the terms of the Creative Commons

Attribution License, which permits unrestricted use and redistribution provided that the original author and source are credited.

Selection and Peer-review under the responsibility of the ICEST 2018 Conference Committee.

\section{G OPEN ACCESS} stage. The quality of problem-based mathematic learning model refers to quality criteria according to Nieveen that includes valid, practical, and effective criteria. The problembased mathematic learning model was tested to the students of PGSD Department of FKIP, Bung Hatta University involving 30 students and 3 mathematic lecturers. The instrument used in this study consisted of 1) instrument of validity appraisal, component of learning model and toolkit, 2) instrument of practicality appraisal from students and lecturers, 3) effectiveness instrument covering test result and students' appreciation appraisal toward problem-based mathematic learning model. The result showed that problem-based mathematic learning model including syntax/learning steps, along with learning tools in term of semester learning plan and students' worksheet was considered valid, practical, and effective.

Keywords: problem-based mathematic learning, students competence.

\section{Introduction}

To improve the competitiveness of the nation in the face of globalization in all fields, it is necessary for higher education to be capable of developing science and technology and producing intellectual, scientist, and / or professionals who are cultured and creative, tolerant, democratic, tough character, and dare to defend the truth for the sake of Nation (Act number 12 of 2012). Mathematics is one of sciences that studies the logic, form, arrangement, quantity, and concepts related to one each other. Mathematics arises because human thoughts is related to ideas, processes and reasoning. Mathematics also 
supports the development of other sciences, such as physics, chemistry, economics and so forth.

Because the existence and position of mathematics are important, it becomes one of the compulsory subjects in all levels of education (from elementary school to senior high school). However, mathematics is still considered difficult to understand by most learners, including learners in higher education; college student. This difficulty is caused by the fact that the students have found mathematic difficult since they were in basic education level. Due to the hierarchical nature of mathematics, the students brings the problem until they get to higher education [1].

Mathematical hierarchy makes mathematics easy to learn if the mastery of the initial concept has been mastered from elementary school level. Mastery of mathematical concepts is largely determined by the learning process undertaken in school. To achieve the learning process as stated in Government Regulation No. 32 of 2013 and Law no. 20 Year 2003 article 15 it is required to provide components that can support the learning process. One of the learning components is strategy and teaching method in learning process that support education to run effectively and efficiently. Mathematics learning in universities still encounters obstacles and difficulties that result in the less quality output and outcomes of graduates. The difficulty encountered by lecturer and teacher in teaching is that the learners tend to complain that the learning of mathematics is boring and theories studied are irrelevant to the conditions that occur in [2]. In addition, the educators themselves can also be boring and irrelevant in the eyes of students. Students may not understand that learning mathematics can be very interesting if it is presented using interesting, realistic and contextual approach. Therefore, the appropriate learning model is required.

One of the learning models that need to be developed is problem-based learning. Problem Based Learning (PBL) model is a learning strategy that exposes students to practical problems as a foothold in learning or in other words students learn with problems [3]. Problem-based learning models can develop students' logical, critical, creative thinking skills [4].

Based on the experience of researchers in teaching mathematics in the department of PGSD (approximately 12 years), it can be concluded that many students still have problem learning mathematics. Of the entire PGSD students, only $10 \%$ of students were fond of mathematics (source: PGSD prodi file). There were $60 \%$ of students who forgot the concepts that should have been mastered at the elementary or high school level. So before the teacher presents the material on the course of learning mathematics, the 
material studied in high school, even the material at elementary school level should be recalled first.

Other than the lack of mastery of the basic concepts of mathematics, $65 \%$ of students immediately got shocked if a problem or a rather complex math problem was given. If the students were able to parse the problem a bit and think logically then the problem was very easy to solve. And if given a different problem from the example given problem, $65 \%$ of students also immediately gave up and could not complete it. If students can be more critical and creative, they will be able to solve the problem easily. This shows that the students' ability of thinking logically, critically and creative students was low. This is assumed as a factor making students' achievement low.

This study aims to produce a model of mathematics learning with a problem-based learning approach in the form of learning tools (Semester Learning Plan and LKM) on valid, practical and effective mathematics learning. Learning is the process of student interaction with lecturers and learning resources in a learning environment (Law no 12 Year 2012). Learning is an effort or attempt to create conditions that enable students to learn actively, get to know and understand learning materials better [5]. Learning is an active student learning activity, emphasizing the provision of learning resources" [6]. Mathematics learning requires students to build their own understanding through their efforts. Learning mathematics also requires a high process of reasoning, and how to apply the rules and concepts into the real life mathematics. The learning of mathematics, there are two objects obtained by the students; direct and indirect objects. Direct objects include the ability to investigate and solve problems, independent learning and know how to learn properly. Meanwhile, the indirect objects are facts, skills, concepts and rules [7].

So in learning mathematics, the students will find a variety of facts, skills, concepts and specific rules. In addition, they will also acquire the ability to investigate, solve problems and learn independently. Therefore, they are required to be actively and creatively involved in learning. This is expected to be in line with the objectives of Maths lesson namely; (1) to train thinking and reasoning in drawing conclusions, developing creative activities involving imagination, intuition and discovery by developing divergent, original thinking, curiosity, making predictions and guessing, and practicing, and (2) to develop problem-solving skills, develop the ability to convey information / communicate ideas, among others through oral conversation, graphics and maps in explaining the ideas [8].

Based on the above theory, mathematics learning trains students to get used to reasoning in conclusion, used to be critical in facing problems, be able to develop their creative ability, to develop their ability in problem solving. Then, the students are expected 
to develop their ability in explaining their ideas through graphs, maps, and speeches orally.

Models are conceptual framework arranged in logical and systematic order as guidance in conducting an activity. It can also be interpreted as a model of a conceptual structure that has been successfully developed in a field and is applicable, especially for guiding research and thinking in other fields, usually in a less developed field [9]. The model as an object or concept used to present something real and then converted into a more comprehensive form [10]. The most widely used models are physical, computer, and mathematical models. All models have "if-then" properties, and they are tied to the theory [11]

The above definition contains three main components in the so-called model: 1) frame or abstraction or conceptual representation, 2) regular or structured and integrated, and 3) used for thinking and working guidance. These three components are an integral whole that should be available in a model, including the learning model.

Model of teaching is an overall plan, or pattern for helping student to learn specific kinds of knowledge, attitudes or skill. In other words, the learning model is a plan or pattern prepared to help learners more specifically on different knowledge, attitude or skills [10]. A model of teaching is a plan or pattern we can use to design face to face teaching in classrooms or tutorial setting and to shape instructional material-including books, film, tapes, and computer-mediated program and curriculums (long term courses of study) [12]. That is, the learning model is a plan or a pattern used as a guide in planning the learning in the classroom or tutorial learning and to determine learning tools such as books, films, tape recorders, computers, kurilkulum, and so forth. The model as a regular and systematic work procedure containing thoughts, descriptions or explanations of a concept [13]. Learning as a process of interaction of educators with learners who can encourage them to learn actively, creatively, and interactively using methods, approaches, tools / media, and the appropriate learning environment [5]. Learning as the basis for the process of adding new information and ability [14].

Problem-based learning is a learning approach that uses real-world problems as a context for students to learn critical thinking and problem-solving skills and to acquire knowledge and concepts that are essential from the subject matter [4]. Problem based learning is a learning strategy by confronting students learn through problems [3]. Based on the previous opinion, it can be concluded that the problem-based learning model is a series of learning that makes the problem as a material for learning. The problem-based learning model consists of five steps: (1) Orienting students to problems, (2) Organizing students to learn, (3) Guiding individual / group experiences, (4) Developing and 
presenting works, (5) Analyzing and evaluating problem solving process. From these Problem Based Learning steps, it is possible to develop students' critical and creative logical thinking ability in formulating problems, processing information and analyzing problem solving process. The increase of students' logical, critical and creative thinking will improve student learning outcomes [4].

Problem-based learning is a model of structured learning that can help students to build knowledge and problem-solving skills and to master knowledge [15]. In practice, problem-based learning creates contextual problems as the beginning of the learning process. Problem-solving at the beginning of the learning process is a major characteristic of problem-based learning [16]. [17] includes: (1) deriving question or problem, (2) interdisciplinary focus, (3) authenthic investigation, (4) production of artifacts and exhibits (5) collaboration. Furthermore, [17] add one feature more in problem based learning, namely (6) problem solving. The problems presented in problem-based learning are related to the daily life of the students, meaningful and complex or avoid simple answers. In problem-based learning models, the necessary knowledge in the investigative process also includes knowledge in other areas that students have had previously. Furthermore, in the investigation process to find solutions, students need to analyze and define problems, develop hypotheses and make predictions, collect and analyze information, conduct experiments (if needed), and make conclusions. Furthermore, problem based learning models also requires students to produce a product (artifacts) to be presented to other students. Another thing covered in the problem based learning models is collaboration. In problem based learning models, the process of investigation and problem solving done by the students is carried out with one friend or in small groups. Furthermore, problem-based learning also has several advantages, one of which can help improve achievement and high-order thinking [17]. Furthermore, research studies conducted by $[18,19]$ showed that problem-based learning could improve learning achievement. Thus, problem-solving learning can be an option in mathematics learning that has a great opportunity to achieve the objectives of mathematics learning. In accordance with the above explanation, the learning of mathematics is always necessary to do development. Thus this research aims at developing a model of problem-based mathematics learning that meet the valid, practical, and effective criteria that can be applied in learning mathematics.

\section{Researh Method}




\subsection{Type of research}

This research is a type of research development or development research (RnD). The development model used in this study refers to the development stage according to Nieveen which includes (1) preliminary stage, (2) prototyping stage (introduction stage), (3) assessment stage [20]. Furthermore, the quality of the problem-based mathematics learning model also refers to the criteria of quality according to Nieveen that include valid, practical, and effective criteria [20]. This study aims to develop and produce a model of mathematical learning with a Problem-based learning which produces learning tools (Syllabus, Learning Plan, and LKS) that are valid, practical and effective and enhance students' logical, critical and creative thinking skills. To measure the validity of the product, expert judgment/expert test and focus group discussion were conducted. Meanwhile, practicality was done by testing the application of products to students in the form of a questionnaire of practicality.

\subsection{Time and place of research}

This research was conducted in the even semester of 2016-2017, in the study program of Teacher Education of FKIP Elementary School of Bung Hatta University Padang.

\subsection{Target / subject of research}

The development of this problem-based mathematical learning model involved three experts namely lecturers from the Elementary School Teacher Education Program to determine the validity of the learning model. Furthermore, the try-out of the problembased mathematics learning model involved 30 students who took the course of Mathematics Learning II.

\subsection{Research procedures}

The procedure for developing the problem-based mathematics learning model consists of (1) preliminary stage, (2) prototyping stage (stage of prototyping), (3) assessment stage. Preliminary stage covered preliminary study, reviewing related-studies, and literature review. Preliminary study was conducted by giving a questionnaire to the lecturer of math course. Furthermore the result obtained at this preliminary stage was used to 
design the learning model planned. At the prototyping stage, learning model components, learning support tools, and instruments to assess the quality of the developed learning model were planned. Furthermore, the result of planning of learning model, instruction-supporting tools and assessment of the quality of the model of learning were assessed by the expert to measure their validity. Then, the model of learning from the results of expert judgments was revised based on the comments given. The valid learning model was then tried-out on the students who took the course of Mathematics Learning 2.

In the assessment phase, the learning model that has fulfilled the valid criteria was tried-out in the learning process of the mathematics course II. The practicality of learning model was judged by 3 lecturers and 30 students. Furthermore, the effectiveness of the learning model was determined by the learning outcomes and the students' appreciation of the problem-based mathematics learning.

\subsection{Data, instruments, and data collection techniques}

This study used quantitative and qualitative data. Quantitative data were obtained from the results of the assessment sheet of expertise and by the expert, the practicality assessment sheet from lecturers and students, the results of students' achievement in mathematics course II and the results of observation. Meanwhile qualitative data obtained were suggestion and feedback either from the expert (lecturer) or students as an improvement model of learning.

\subsection{Instruments}

The instruments used in this study were (1) a validation instrument that includes (a) a validity assessment sheet and a learning model component, and (b) the scoring sheet to support learning (RPS, MFI, THB); (2) the instrument to score practicality that includes (a) the assessment sheet from the lecturer, and (b) assessment questionnaire from the students; And (3) the effectiveness assessment instrument that includes (a) achievement sheets, and (b) the student's appreciation sheet on problem-based mathematics learning; (3) instruments to develeop student competence. 


\subsection{Data analysis}

The validity of the problem-based mathematics learning model were determined by expert judgment. Scores obtained from the validity of assessment sheet, the practicality and effectiveness of the learning model were converted into qualitative categorization, with reference to the categorization, like the following table.

TABLE 1: qualitative categorization.

Interva of Score
Average
$4.00 \leq X<3.00$
$3.00 \leq X<2.00$
$\leq X<1.00$
$1.00 \leq X<0.00$

\begin{tabular}{|c|}
\hline Value \\
\hline$A$ \\
\hline$B$ \\
\hline C \\
\hline $\mathrm{D}$ \\
\hline
\end{tabular}

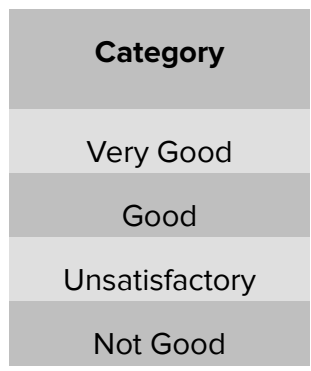

The learning model is considered valid if at least the expert's assessment of the learning model components and learning support tools is good. Furthermore, the problembased mathematics learning model is considered practical if the results of lecturer and student appraisals are good. The effectiveness of learning is determined by the learning outcomes and the level of student appreciation of problem-based mathematics learning. Problem-based mathematics learning model is considered effective if the completion of classical learning at least by $75 \%$ with a minimum value of $B$. In addition, the problembased mathematics learning model is considered effective if the level of student appreciation of problem-based mathematics learning at least achieve effective criteria.3.

\section{Result and Discussion}

Learning developed in this research was problem-based mathematic learning consisting of syntax / learning step, social system, reaction principle, social system, and instructional and follow-up impact. The following was the results of this development research. The results of expert assessment to the validity of the problem-based mathematic learning model showed that the components of problem-based mathematics learning was very valid. The results of the expert assessment on the components of problem-based mathematical learning model can be seen in following Table.

In score and Criteria for Assessment of validity of problem-based Math learning model, the lecturer generally played a role to present the problem and guide the students to be able to dig up any information that was known about the problem, to make the list of questions and to record initial thinking and problem-solving planning. During the try-out 
TABLE 2: Scores and result of validity of Assessment on the problem-based mathematic learning model.

\begin{tabular}{|l|l|c|c|}
\hline NO & COMPONENTS & Score Average & Criteria \\
\hline 1 & Syntax & 3.7 & Very Valid \\
\hline 2 & Social System & 3.6 & Very Valid \\
\hline 3 & Reaction Principle & 3.6 & Very Valid \\
\hline 4 & $\begin{array}{l}\text { instructional and } \\
\text { follow-up impact }\end{array}$ & 3.5 & Very Valid \\
\hline
\end{tabular}

of learning model for 8 meetings, the orientation stage on the problem in mathematics learning could be accomplished throughout the meeting; (2) Student management to learn, was focused on student to study in group where student study group was deteremined by lecturer. At this stage students were also required to be able to determine the source of learning that can be used to solve the problem. Furthermore, the results of the validity assessment of learning media are summarized in Table 3 below.

TABLE 3: Scores and Results of validity Assessment of problem Based Math learning tool.

\begin{tabular}{l|c|c|}
\hline Product & Score Average & Criteria \\
\hline RPS & 3.5 & Very Valid \\
\hline LKM & 3.6 & Very Valid \\
\hline LEARNING & 3.7 & Very Valid \\
\hline ACHIEVEMENT & & \\
\hline
\end{tabular}

Based on Table 3, three devices were very valid. Furthermore, the results of the practicality assessment from the students also showed that the problem-based mathematics learning model was very practical (3.8).

The try-out of problem-based mathematics learning on PGSD students ran very well although students experienced obstacles in the beginning. Moreover, the given problem had a divergent answer. So it was very necessary to have the students' different answers. Moreover, the answer column provided did not require the problem solving stage. So, the student creativity could be improved. The impact of the learning process that ran well was reflected from the results of students' good achievement. Based on the students' learning achievemnt, $90 \%$ of student got $B$ value. This means that learning of thematics using problem based learning was effective. The level of students' appreciation to the problem-based mathematics learning model was very good (3.8).

In the process of problem solving, after students successfully determined the appropriate problem-solving strategy, then the next thing done by the students was to implement the strategy. During the learning process, students were given the freedom to be able to determine and execute existing problem-solving strategies. The lecturer in this 
case acted as a facilitator and simultaneously as an evaluator to help to ensure students that the steps taken by the students were correct. During the problem-solving process, the lecturer always reminded the students to check the calculation and the steps taken by the students in order to make sure that the answer or completion obtained by the student was correct. However, some students were found to skip stages to rethink or recheck answer of problem solving. Then, the questionnaire data from students' appreciation on problem-based mathematics instruction also showed that the appreciation of students to instruction was effective. Thus it can be said that the problem-based mathematic instruction model was effektif.

Based on the analysis above, it can be stated that the development of problem-based mathematics learning is valid, practical and effective, so that it can be considered to be used in the learning of mathematics in School.

\section{Conclusions and Suggestions}

Based on the stages of development conducted, a problem-based learning model could be created. Problem-Based Mathematical Learning Model fulfilling the valid, practical, and effective criteria consists of components (1) syntax of problem-based mathematics learning covering steps that are (a) students' orientation on a problem, (b) students' orientation to learn (c) solving a mathematical problem that includes understanding the problem, planning the strategy, executing the strategy, and reviewing the solutions obtained, (d) the presentation of the work, and (e) the analysis and evaluation; (2) social system in problem-based mathematics learning is that a lecturer acts as a facilitator and evaluator of mathematic problem solving process, the instruction is cenetered on problem solving process by student and the student can express opinion; (3) the principle of reaction in problem-based mathematics learning is that lecturer guides and emphasizes on the process of problem-solving in mathematics by the students, the lecturers evaluate and provide feedback on the results of mathematic problem solving by students; (4) the supporting system on problem based mathematic learning is contextual concern and related to daily life of students covered by LKM, availability of learning resources and visual aids; (5) the impact of problem-based mathematics learning is competency achievement and mathematical problem solving process, while the follow-up impact is the skills to cooperate, improve the ability of thinking logically, critically and creatively.

The validity of model of problem-based mathematics learning was based on expert judgments, namely (1) syntax, social system, reaction principle, and instructional and 
follow-up impact was very valid; (2) learning tools in the form of RPS, MFIs and Test of Learning Outcomes were very valid. The practicality of the problem based mathematics learning model was based on (1) the assessment of the lecturer was very practical; (2) assessment of the students was very practical. The effectiveness of the problembased mathematics learning model was based on (1) the result of the students' THB was effective with the percentage of students achieving the minimum value of $B(90 \%)$, (b) the students' appreciation of the problem-based mathematics learning was good. Thus the problem-based mathematics learning model that has been developed was valid, practical, and effective, so it is suggested to use mathematics learning developed as one of mathematic learning models which is expected to be able to increase student's competence.

\section{Acknowledgements}

On this occasion, we would like to thank those who have helped us to be able to conduct this study; The Ministry of Research and Technology, High Education (funding supporter of this research), the Rector of Bung Hatta University, the Head of Research Center of Bung Hatta University, the Dean of FKIP of Bung Hatta University, Validators, and English Translator.

\section{References}

[1] Amrina, Z. (2015) Analysis Of Students' Logical Thinking Competences In Mathematics Class In Grade V At The State Elementary School 10 At Sungai Sapih In Padang, Proceding The 1st International Conference of Elementery School Teacher Education, UNJ Jakarta.

[2] Fiet, J. O. (2001). The pedagogical side of entrepreneurship theory. Journal of Business Venturing, 16(2).

[3] Wena, M. (2003). Strategi Pembelajaran Inovatif Kontemporer. Jakarta timur: Bumi Aksara.

[4] Amrina, Z. (2014) Peningkatan Kreatifitas Siswa Melalui Problem Based Learning, Jurnal Cerdas Proklamator ISSN 2338-0926 volume 1 nomor 1, Desember 2014, PGSD FKIP Universitas Bung Hatta.

[5] Sardiman, A.M. (2011). Interaksi \& Motivasi Belajar Mengajar. Penerbit: PT. Raja Grafindo Persada. Jakarta. 
[6] Dimyati dan Mudjiono.(2009). Belajar dan pembelajaran. Jakarta: Direkturat Jendral Pendidikan Tinggi.

[7] Suherman, E. (2003). Strategi Pembelajaran Matematika kontemporer. (edisi revisi). Bandung: FMIPA UPI.

[8] Depdiknas. (2003). Kurikulum 2004. Jakarta: Depdiknas.(2003)

[9] Marx, M.H. \& Goodson, F.E. (1976). Theories in Contemporary Psychology. New York:MacMillan.

[10] Meyer, R.E. (2011). Review of Educational Research. New York: McMillan.

[11] Snelbecker, G.E.. (2012). Learning Theory, Instuction Theory, and Psychoeducational Design. New York: McGraw-Hill.

[12] Joyce, B. \& Weil, M. (2003). Model of Teaching (Fifth-Edition). New Delhi: Prentice-Hall of India Private Limited.

[13] Prawiradilaga, Dewi Salma. (2008). Prinsip Desain Pembelajaran. Penerbit:Universitas Negeri Jakarta. Jakarta.

[14] Sanjaya, W. (2006). Strategi Pembelajaran: Berorientasi Standar Proses Pendidikan. Penerbit: Kencana Prenada Media Grup. Jakarta (2006)

[15] Delisle, R. (1997). How to Use Problem-based Learning in the Classroom. Alexandria, VA: ASCD.

[16] Barrett, T. Mac Labhrainn, I., \& Fallon, H. (Eds). (2005). Understanding problem based learning dalam Handbook of enquiry \& problem based learning. Galway: CELT.

[17] Arends, R.I. \& Kilcher, A. (2010). Teaching for student learning: Becoming an accomplished teacher. New York: Routledge.

[18] Kohlhaas, B. (2011). A study of problem based learning in the middle classroom.

[19] Smith, M. \& Cook, K. (2012). Attendance and achievement in problem-based learning: The value of Scaffolding Interdiciplinary Journal of Problem-based Learning: Vol. 6: Iss. 1, Article 8.

[20] Nieveen, N. (1999). Prototyping to Reach Product Quality. Dalam J.V.D Akker et. al (Eds), Design Approaches and Tools in Education and Trainning. Netherlands, Dordsrecht: ICO Cluwer Academic Publisher. 